Bedford-Strohm, Heinrich ${ }^{1}$

Bamberg University / Stellenbosch University

Poverty, wealth and ecology - A theological perspective

\begin{abstract}
Reflecting on poverty, wealth and ecology - and connecting it with a call for social and environmental transformation - demands an understanding of the

present and at the same time a vision of a transformed future. For this reason this the essay takes as point of departure a fictitious newspaper report on a conference in 2100 that reflects on the history of the world over the past century, a history of exploding globalization, economic injustice, massive growth in the divide between rich and poor and increased ecological degradation. All of this, this according to the report, lead to a gradual global change in consciousness and efforts to address these challenges to make the twenty-first century an age of global transformation towards a true "world society". In light of this fictitious future, our societies, but especially also our churches, and where they find themselves today are reflected upon. Then some of the sources we come from, beginning with the Bible and continuing onto some of the rich traditions of our churches is followed by an appeal for overcoming certain false alternatives in how we as churches act in a developing global civil society.
\end{abstract}

\title{
INTRODUCTION
}

Reflecting on poverty, wealth and ecology - and connecting it with a call for social and environmental transformation - demands an understanding of the present and at the same time a vision of a transformed future. Sometimes the best way to understand the present is a look into the future. We need distance from the practices of our own time in order to understand the deep contradictions amidst which we live and which we have gotten used to, often without noticing. One of the fascinations of science fiction movies is their implicit or explicit assessment of our own time as either a lost paradise or a dark age from which we will have been delivered in a fictitious future. Being aware of the limits of such simplifications, I want to take the reader into the future for a moment, on a journey into the year 2100; and when we arrive there, to read a news report from the Global Electronic Observer, with two billion subscribers the world's leading newspaper at the beginning of the twenty second century.

The report gives some interesting insights into the results of an international conference of historians, and the reader may recognise him/herself or people he/she knows in the conference discussions:

At an international millennium conference in Cape Town, South Africa, leading historians

1. Heinrich Bedford-Strohm holds the Chair in Systematic Theology and Contemporary theological issues at Otto Friedrich University, Bamberg, Germany. He is Extraordinary Professor in the Theological Faculty of Stellenbosch University and Director of the Dietrich Bonhoeffer Research Centre for Public Theology in Bamberg. BedfordStrohm is also President the Society of Protestant Theology in Germany and Deputy Chairperson of the Chamber for Social Responsibility of the German Protestant Churches. Since 2009 he is main editor of the journal Evangelische Theologie. 
NGTT Deel 54, Nommers $3 \& 4$, September en Desember 2013

yesterday pleaded for new efforts to gain an understanding of the history of the twenty first century. Renowned German historian Michael Misakwani recalled the massive violation of human rights characterising the whole first half of the twenty first century. Misakwani, who has African roots himself, was referring especially to the immense misery that was caused by the lack of food and basic medical care in many countries in Africa. Nowadays 25000 deaths are mourned every day as a result of poverty. Even at that time it was clear that there was enough food and medicine to guarantee an existence minimum for every human individual. Especially in the first decade of the twenty first century, wealth in parts of the world increased massively, but was not used to fight poverty determinedly. Not even the global economic and financial crisis of 2008 generated a fundamental reorientation. The guaranteed global basic income that is an entitlement of every citizen of the planet today was seen by many in those days as an illusion, even though the resources were available. According to Misakwani, faith communities continuously and publicly pointed out those global injustices. But many of their members were in positions of power without using it to stop the immense poverty that caused violations of human rights. Until today historical science has not really understood how this could happen.

Harvard historian John Obama, a descendant of the first black president of the USA, pointed out the complexity of the economic situation in those first decades of exploding globalisation. The economic dynamic was so strong that the humanitarian dynamic did not keep up with it. Many of the leading economists and politicians of the time honestly thought that overcoming poverty would automatically follow if economic activities were hindered as little as possible. Therefore, they did not realise the moral ambiguity of the existing economic system.

A widely acknowledged point was made by Chinese church historian Ka Wee Yan. Yan, who represented the OECC (One Ecumenical Church of Christ) at the conference, analysed the role of the churches in her lecture. According to Yan, the churches - which were still divided in different denominations then - were in many cases so occupied with themselves that they underestimated the moral volatility of the situation. In addition, despite media coverage on a global scale, direct confrontation with daily misery and death was lacking in the churches of the North. At the time many Christians, when they were personally confronted with such misery, were already engaged in helping those in need. However, they deemed global injustices to be insurmountable - as little as this is understandable from a contemporary point of view. Yan advocated further efforts for a just and sustainable future. Even though, in the past decades, it was made possible for every human being to live without serious material concerns, the complete integration of robot technology into daily environments has created new challenges for human social life.

Australian historian Irabinna Ngurruwutthun spoke about ecological reorientation in the twenty first century. Today we can hardly imagine the massive amount of violence that human beings had perpetrated against the earth at the beginning of the twenty first century. At the time people spoke of "garbage" referring to many things used in daily life. They burned or buried these materials. With some materials, such as glass and paper, recycling processes were already in use. According to Ngurruwutthun, the complete recycling system that we are used to today was, however, considered too expensive at the time. In only a few decades those societies extracted precious resources from the earth, resources that took millions of years to form. The great resettlement programmes of the last decades, said Ngurruwutthun, 
NGTT: Oopbron - http://ngtt.journals.ac.za

had become necessary because of massive climate change that was still developing more or less unrestrained at the beginning of the twenty first century and which had led to a considerable rise in sea levels. Many politicians and scientists of the time still thought that a complete conversion of energy supplies to regenerative sources was an illusion - a process that was completed later, by the middle of the twenty first century. Lifestyles were still based on wastage of water and energy. Only through the well organised internet based global civil society movements of the early twenty first century did a fundamental change in consciousness occur. The Australian historian further emphasised that today we cannot even imagine anymore why a century ago people considered ever more material consumption to be a source of happiness. This insight, she said, should teach present generations to overcome contemporary ignorance on issues of the future.

Various other contributions to the symposium emphasised in a similar way the necessity to learn from history. The general perception was that the twenty first century occupies a special place in modern history, a place only comparable with the age of the Reformation in Europe when constellations were formed that shaped the centuries that followed. The twenty first century was seen as the age of global transformation towards a true "world society". The reflections that follow here are nothing more than a commentary on this news report. My comments are firmly rooted in the theologically based conviction that another world is possible and it reflects a reading of the signs of the times today that sees God at work. Nobody described this theological basis as clearly as Dietrich Bonhoeffer. In his Ethics fragments, written only a few years before his execution by the Nazis, Bonhoeffer affirms his Christological understanding of reality and emphasises the necessity of fully engaging in worldly reality without simply repeating what the world says:

In Christ we are offered the possibility of partaking in the reality of God and in the reality of the world, but not in the one without the other. The reality of God discloses itself only by setting me entirely in the reality of the world, and when I encounter the reality of the world it is always already sustained, accepted and reconciled in the reality of God. This is the inner meaning of the revelation of God in the man Jesus Christ (Bonhoeffer 2005:55).

From this perspective our reading ofreality can neither demonise the world nor remain blind to its grave inner contradictions. It looks instead at the world with love that includes grief in the face of suffering as much as hope in light of potential change. I will, therefore, after this first introductory step, look at where we find ourselves in our societies but especially also in our churches (2). I will then recall some of the sources we come from, beginning with the Bible and continuing onto some of the rich traditions of our churches (3). I will, furthermore, plead for overcoming certain false alternatives in how we as churches act in a developing global civil society (4) and then conclude (5).

\section{Where are We?}

What, Dirkie Smit once asked, is globalisation? Then he added, "There simply seems to be no satisfactory answer to this question" (Smit 2007:125). Moreover, an assessment of the risks and chances of our increasingly globalising economy is highly dependent on its starting point. If we assess globalisation in terms of developments from an earlier period, we are faced with both good and bad news. Many people are materially better off. Some countries, notably in China and Brazil, have progressed considerably in combating poverty and developing their 
NGTT Deel 54, Nommers $3 \& 4$, September en Desember 2013

economies. If we consider the overall global picture, however, far too many people's situation has remained miserable or has worsened. As far as ecological destruction is concerned the overall situation has definitely grown worse, especially due to climate change and its negative impact, primarily on many poor countries. Questions regarding ecological justice are only beginning to appear in international debates. Given these downsides, the overall assessment of the 2010 United Nations Human Development Report is relatively optimistic in its assessment of the global human development indicators, even though backlashes are mentioned as well. For the first time the authors looked at long term developments. They summarised as follows:

The past 20 years have seen substantial progress in many aspects of human development. Most people today are healthier, live longer, are more educated and have more access to goods and services. Even in countries facing adverse economic conditions, people's health and education have greatly improved. And there has been progress not only in improving health and education and raising income, but also in expanding people's power to select leaders, influence public decisions and share knowledge. Yet not all sides of the story are positive. These years have also seen increasing inequality - both within and across countries - as well as production and consumption patterns that have increasingly been revealed as unsustainable. Progress has varied, and people in some regions - such as Southern Africa and the former Soviet Union - have experienced periods of regress, especially in health (UNHDR 2010). ${ }^{2}$

If we do not base our assessment of globalisation on relative improvements but on normative accounts of what would be a "natural" situation, the conclusion is far more negative. ${ }^{3}$ Every human being dying from lack of food or medication represents a serious moral shortcoming. Moral questions of this kind are a matter not only of ethics but of ecclesiology (Smit 2007:262-269). Faith in the triune God is inseparably linked to human dignity (Koopman 2010:231-236). This is why the churches' assessment of globalisation has and must have an inbuilt critical bias. Even if we could name considerable improvements, we can never be satisfied with the speed or extent of the process. To be sure, assessments of what the best options would be to improve the situation are highly relevant. We, therefore, need an intensified discourse in the scholarly world as much as in the churches on this exact question.

Dirkie Smit has given an insightful overview of some recent scholarship on globalisation in the global South that has not been acknowledged and reflected upon enough in Northern discourse (Smit 2009). In a recent excellent, comprehensive article on the discussion in the

2. The report summary continues: "In some basic respects the world is a much better place today than it was in 1990 - or in 1970 . Over the past 20 years many people around the world have experienced dramatic improvements in key aspects of their lives. Overall, they are healthier, more educated wealthier and have more power to appoint and hold their leaders accountable than ever before. Witness, for example, the increase in our summary measure of development - the Human Development Index (HDI) - that combines information on life expectancy, schooling and income in a simple composite measure. The world's average HDI has increased 18 per cent since 1990 (and 41 per cent since 1970), reflecting large aggregate improvements in life expectancy, school enrolment, literacy and income. But there has also been considerable variability in experience and much volatility."

3. See also Section IX of the final document of the 10th Assembly of the Lutheran World Federation (Winnipeg, 2003) entitled "Transforming Economic Globalization". 
NGTT: Oopbron - http://ngtt.journals.ac.za

churches, Konrad Raiser has shown how many churches in Europe and worldwide have addressed the challenges of globalisation in public statements (Raiser 2009). Among the most vigorously discussed contributions to an on-going debate are: the document produced by the 24th General Assembly of the World Alliance of Reformed Churches (WARC) in August 2004 in Accra, Ghana; the World Council of Churches (WCC) document Alternative Globalization Addressing Peoples and Earth (the so called AGAPE document) produced in 2005 in preparation for the 9th Assembly of the WCC in Porto Alleger in February 2006; the Conference of European Churches' 2005 statement, European Churches Living Their Faith in the Context of Globalization; the German Protestant Churches (EKD) synod's Organizing the Global Economy Responsibly, issued in 2001 already; and the 2005 document by the Swiss churches, Globalance. Christian Perspectives on Globalisation with a Human Face (Swiss Church Federation). ${ }^{4}$

Since the Porto Alegre Assembly the world has experienced a serious economic and financial crisis that confirmed some of the worst fears that the ecumenical movement had been expressing for a long time. The WCC Central Committee (meeting in Geneva, Switzerland, 26 August to 2 September 2009) called upon governments to take actions that would clearly show that a fundamental reorientation was required regarding the dominant ways of doing economics. Similar insights can be gained from a recently published book, a fruit of the WCC's now continuous study on poverty, wealth and ecology. Justice Not Greed was produced by the WCC Advisory Group on Economic Matters and can be seen as a call to finally face the consequences of the highly ambiguous global mechanisms, which are even more evident now than before the crisis (Brubaker and Mshana 2010).

I shall not repeat the contents of all these statements and documents. What I want to comment on is the lack of impact it had on public discourse, which makes no sense. The Christian churches represent one of the most important religious traditions in the world. It lies in the nature of religious traditions to touch the deepest levels of existence in their followers - and to open their wallets. People give tremendous amounts of money to their religious communities. But, and this is even more important, religious traditions also have power over their members' souls. Therefore, at a global level - as Piet Naudé rightly stated - "the institutional church's witness against the systemically uneven distribution of economic goods in the world and the declaration of a confession like that of Accra should not be underestimated" (Naudé 2010:215). Yet the churches have not lived up to their potential in this respect. There has been an illogical and unsatisfactory impact on global political life by statements on economic justice issued by ecumenical bodies. Especially in the wealthy countries of the North, where many of the far reaching decisions regarding the global economy are made, Christianity is the formative religious tradition. If the churches in these countries, together with the churches worldwide, would succeed in drawing Christians in their sphere of influence into a process of ethical

4. The report summary continues: "In some basic respects the world is a much better place today than it was in 1990 - or in 1970 . Over the past 20 years many people around the world have experienced dramatic improvements in key aspects of their lives. Overall, they are healthier, more educated and wealthier and have more power to appoint and hold their leaders accountable than ever before. Witness, for example, the increase in our summary measure of development - the Human Development Index (HDI) - that combines information on life expectancy, schooling and income in a simple composite measure. The world's average HDI has increased 18 per cent since 1990 (and 41 per cent since 1970), reflecting large aggregate improvements in life expectancy, school enrolment, literacy and income. But there has also been considerable variability in experience and much volatility. 
NGTT Deel 54, Nommers 3 \& 4, September en Desember 2013

reflection and self-examination on their place in and possible calling towards the economic life, the seed for a reorientation of global economic life would have been planted. Why has this not happened? In short: because churches have not listened to each other and, therefore, have not found a unified voice in global civil society.

Many voices in the North have reacted against the radical condemnation of globalisation in the Accra and AGAPE documents. Many of those who at least took notice of these documents are closely connected with market economies as consumers, business people, employees or politicians. They could not see those statements as helpful contributions, because they did not see the value of these documents for orienting daily life and the political processes in their own countries. What some critics in the North do not understand is the clear focus of Accra and AGAPE on neoliberal globalisation as an ideology. They read these documents as a condemnation of globalisation as such, rather than a condemnation of a certain version of globalisation. Maybe they also do not sufficiently understand, in their very souls, how destructive the concrete experience of capitalism has been in many countries of the South.

On the other hand, the detrimental effects of certain practices of global trade have had such a an impact on the South that those countries do not see the marked differences between Swedish social democratic policies and the rigorous free market policies of the Bush administration. Although both approaches go under the label of capitalism, their consequences are very different, and so is their moral value. Especially in light of the situation in Europe, the label "neoliberal globalisation" and the notion of "empire" do not sufficiently take into account these widely differing approaches. In Germany, for example, where the model of a social market economy is held in high esteem in the social teaching of the churches, the ecumenical documents are misunderstood as constituting a critique on market approaches as such, including the social market approach. Therefore, to some people in the Northern churches these documents seem easy to dismiss. The potential for common ground has been overlooked.

It is time to move beyond such miscommunication. It is, above all, the biblical tradition and its reflection in the churches' teaching that creates such common ground. What I shall give now is not an in depth analysis of all these teachings, but a kind of summary. The purpose is to highlight the surprising extent of the consensus across the vastly different traditions we come from. If we could raise an awareness of this common ecumenical ground, the churches might gain new momentum in forming a strongly united ecumenical voice in global civil society.

\section{WHERE DO WE COME FROM?}

The biblical option for the poor has become a key phrase for a characteristic of both the Old and the New Testament that has gained wide acceptance in churches all over the world. No ideological distortion of the biblical witness has ever been able to extinguish this keyfeature of the Bible, so prominent in its various layers. We only have to recall the notion of humankind being the image of God, which forms the basis of equality, or the astonishing fact that the very founding story of God's people is a story of liberation from slavery. We may simply look at the specific character of the Torah as protecting the weak and marginalised, or listen to the prophets' passionate critique of a religious cult that ignores the struggle for justice. We only have to consider Jesus' understanding of his mission as proclaiming the good news to the poor (Luke. 4), his critique of wealth detached from the needs of the community, and his radical identification with those who are hungry, thirsty, naked, strangers or sick 
NGTT: Oopbron - http://ngtt.journals.ac.za

(Mt. 25).We simply have to make an effort to understand the deep socio ethical implications of a God's incarnation on earth that ended in him becoming a victim of torture, and we need only take seriously Paul's reflection on the cross as a key to God's work in the world (1 Cor. 1). If we reflect on all of this, we cannot but understand that concern about the situation of the poor and disadvantaged, and making every effort possible to improve their situation, is not a special interest of some politically biased Christians influenced by radical theologians; it is a central characteristic of the Christian understanding of God and, therefore, an indispensable dimension of Christian faith and the personal practice that flows from it in every Christian's life - including its political consequences.

It is, therefore, not surprising that in the foundational traditions of the churches and the denominational expressions thereof, this concern plays a special role. Alexandros Papaderos has shown how the witness of the church fathers, so central to the Orthodox tradition, has always expressed this concern. He quotes Basil the Great in his homily against the usurers, condemning oppressive attitudes towards the poor that are guided by greed and selfcenteredness (Papaderos 2005:78). He points out how John Chrysostomos continuously admonished the wealthy to share their possessions with the poor (Papaderos 2005:79). Many other examples could be given.

A similar plea on behalf of the poor can be found in Martin Luther's work. Whole libraries have been written on his doctrine of the two kingdoms and his rediscovery of the idea of justification by faith. However, Luther's ethic of economics, with its passionate critique of early capitalism, seems widely forgotten. Even in the Lutheran world almost nobody knows that Karl Marx quoted Luther many times in his famous Das Kapital - in most cases affirming Luther's views. Luther's critique of the practices of banks and multinational corporations of his time, such as the Fuggers, cannot be directly applied to our world. It was motivated by a conservative defence of the old feudal system. Nonetheless, his scepticism about the new practices of early capitalism was fed by the biblical command to love and by the Golden Rule, which he interpreted in a way similar to what we today call the "preferential option for the poor". Regarding the economic practice of multinational companies, such as the Fuggers (who at that time were growing powerful), Luther states:

Kings and princes ought to look into this matter and forbid them by strict laws. But I hear that they have a finger in it themselves, and the saying of Isaiah [1:23] is fulfilled, "Your princes have become companions of thieves." They hang thieves who have stolen a gulden or half a gulden, but do business with those who rob the whole world and steal more than all the rest, so that the proverb remains true, "Big thieves hang little thieves." As the Roman senator Cato said, "Simple thieves lie in dungeons and sticks; public thieves walk abroad in gold and silk" (Luther 1962:271-272).

These words express a protest against the alliance of power and money that denies the interests and rights of the poor. If we look at the work of John Calvin and its connection to modern capitalism, most people think of Max Weber's thesis on the close connection between Calvinism and capitalism. It has, therefore, often been overlooked that for Calvin himself economic activity undoubtedly came with a social obligation. Matthias Freudenberg has shown how Calvin emphasised the social responsibility of wealth. According to Freudenberg

5. For a closer look at Martin Luther's ethics of economics see BedfordStrohm 2008:151-154. There is an excellent interpretation of Luther's works on these lines from a South African perspective that has not received the attention it deserves, namely Nürnberger 2005. Cf. also Duchrow 1987:53-56. 
NGTT Deel 54, Nommers $3 \& 4$, September en Desember 2013

(2009:163), while Calvin was no social revolutionary, he "pleaded for a balance between economic growth and social justice."

An assessment of later Calvinism in theological scholarship, too, results in a different understanding than popular use of the Weber thesis might suggest. In an article on charging interest in the Reformed church, German early twentieth century church historian Karl Holl comes to the conclusion that Calvinism was "the strongest enemy of capitalist striving" until the middle of the seventeenth century (quoted in Körtner 2008:211). Ulrich Körtner has even stated that original Calvinism always tended to turn towards Christian socialism (Körtner 2008:213). In its decisiveness to contribute towards society and its economic wellbeing, says Körtner, Calvinism has always criticised capitalism and called for the church to be socially and practically involved in politics (Körtner 2008:215).

We can thus conclude that not only the Bible but also the teachings of great traditions of our churches speak clearly concerning the moral basis of economic activity. The exclusion of the poor is irreconcilable with the Christian faith. The goal of the economy should be just participation for all members of society.

I cannot discuss here the different traditions with regard to our relationship with nonhuman nature; I have dealt with it elsewhere at length (BedfordStrohm 2001). But what Musa Panti Filibus has described as the consequence of the "principle of enough" can very well be seen as a summary of all the work that has been done in developing a new ecological understanding of creation over the past decades. According to Panti Filibus, an economy built on the principle of enough

...urges us to shape our thinking differently, to recognise that the earth is not just a place for unrestrained growth but also a place of stewardship and responsibility towards each other, a place where human beings can live in peace and justice and, together with all creation, can relax and share God's gifts of nature (Panti Filibus 2010:54).

Closelyechoing this biblical description of our task, German economist Hans Diefenbacher has pointed out the way from a growth oriented world economic system towards one of sustainability:

A way to manage a reduction of economic growth in the developed world by the combination of an efficiency "revolution" and a positive change of lifestyles. Such a strategy would aim at a deliberate and democratically planned reduction of economic growth. Such a reduction would have to be the consequence of political influence and control, a result of changing values in our societies, and not the consequence of a bellicose world economic crisis that inevitably will occur if we keep on following the current growth strategies (Diefenbacher 2011:86).

What Diefenbacher has said regarding the ecological question can be applied to the necessary reorientation of the global economy as a whole: it flows from the Christian faith and its constructive "will to the future" (Bonhoeffer 1972:15f) that we should not wait until some catastrophe forces us to change radically, but that we should become aware that we are not facing a blind fate; we are historical agents who are able to shape the world according to the will of its Creator.

To fulfil the task connected with this vision we need - this is my firm conviction - to develop 
NGTT: Oopbron - http://ngtt.journals.ac.za

a new public theology that is firmly grounded in biblical and theological tradition and at the same time supports concrete political reforms, however limited they may be. If we want to be more successful as churches in making an impact on global economic and political processes, we need to move beyond falsealternatives. In the next section, I shall explain what I mean by that.

\section{TOWARDS A PUBLIC THEOLOGY THAT MOVES BEYOND FALSE ALTERNATIVES}

\section{Inspiration vs. incentive}

The first false alternative I call "inspiration or incentive". In much of the work on economic and ecological justice in the ecumenical movement the existing economic order is criticised because it relies heavily on the profit motive. Indeed, churches around the world widely agree that greed, as an attitude that knows nothing but self-interest, clearly contradicts the Christian faith. But does this apply to the majority of business people who make a living, often a very good living, by profiting from selling their products? Their daily activity as business people is not a charitable activity; it is based on incentives. If it would increase their chances of selling their products they would try really hard to ensure that it is the best on the market. They are not greedy; they pursue their self-interest while respecting everybody else's right to make a living. If they are Christians, they might even stretch their willingness as far as distributing the fruits of their labour among all workers involved in the process without running the risk of going bankrupt. Still, the profit motive plays a role in their economic activity as an incentive beyond pure engagement for the sake of the community.

How do we evaluate their activity as Christians? In many ecumenical documents the instrument of incentives does not play any role. Therefore, any efforts towards an ethic of entrepreneurial action are suspicious - they seem to sanctify what is fundamentally contradictory to gospel values. The WCC Central Committee has stated in its document on Just Finance and the Economy of Life that

...the system that privatizes productive goods and resources, disconnecting them from people's work and needs and denying others access to and use of them is a structural obstacle to an economy of cooperation, sharing, love and dynamic harmony with nature. Alternative morality for economic activity is service/koinonia (fellowship) to human needs; human/social self-development; and people's wellbeing and happiness (quoted in Brubaker and Mshana 2010:219-222).

We can wholeheartedly support this call for an economy of solidarity, love and sharing. All the better if this call is successful and leads to a conversion of all people to this new way of doing economics. However, we must be aware of the fact that this call relies on inspiration, not on incentive. It does not offer any solution to our economic problems short of calling for a world in which people are willing to share freely. This is why I think we need both inspiration and incentive. Concern for incentives is based on the assumption that people do not always spontaneously act in an ethically responsible way but act in such ways only, or only effectively, when it is in their own best interests. A solidarity model of economics would tend to dismiss this assumption because its point is exactly to overcome self interest driven economics. 
NGTT Deel 54, Nommers $3 \& 4$, September en Desember 2013

We have to honour inspirational examples as signs of a new world in which sin has been overcome. But to generate change effectively, we must put equal emphasis on incentives that connect ethical goals with self-interest. These raise, for example, the political question whether incentives have to be created so that it would be in everybody's self-interest to save energy. One of the possible out comes of this reflection would be a call for an ecology tax that makes ecologically hazardous goods expensive and gives market advantages to products that save energy. The appeal to consumers to live more in tune with the environment would be supported by good economic reasons, not only for every individual in his or her consumer habits but also for the companies to produce their goods in ecologically friendlier ways. Ecological consciousness at the sociocultural level would both support and be strengthened by such an ecology tax.

Moving beyond the false alternative of incentive versus inspiration would mean directing much more energy towards conceptualising incentives for ecological and justice oriented economic action. It would mean acknowledging the value of ethically grounded entrepreneurial action, and dialoguing with business people on the ethical dimensions of their daily professional lives. With this I come to a second false alternative.

\section{Prophetic speech vs. dialogue}

The prophetic tradition has always played a prominent role in church history, and with good reason, even though often enough a close alliance between throne and altar has silenced critical voices in order to protect church privileges. Those who voiced prophetic criticism have often been criticised in turn as being naive, unconstructive or overly negative.

On the other hand, defenders of prophetic speech have attacked those in dialogue with power as betraying the moral values of the gospel by adapting according to the demands of those in power. We need to move beyond such false alternatives. We need both prophecy and dialogue, for they have different roles.

The primary task of prophetic voices is to call for repentance and for change of mind and attitude. Therefore, prophetic voices need not always be constructive. They can criticise injustice passionately without necessarily offering a clear practical path towards justice. Yet deconstructive prophetic voices cannot claim any moral superiority over those approaches that work towards justice by means of little steps in the daily political process. There is a time for both; both can even be elements of the same church statement.

Prophecy has an especially prominent role in dictatorships, where fundamental criticism that delegitimizes the system is the most appropriate mode of achieving change. In democratic societies, prophetic speech must be related to the "ecology of consciousness" of a dynamic civil society. If prophetic speech can help to change basic attitudes, it is ethically justifiable and necessary. However, if it prevents a change of mind in the public realm, it may even be ethically questionable.

In a democratic public with many voices but unequal possibilities of drawing public attention, prophetic action, creative forms of protest and civil disobedience in morally crucial situations fulfil an important function. But they must be related to free discourse and the exchange of arguments about the best way to achieve moral goals. If prophetic witness blocks such an exchange of arguments, it is an obstacle to change. The churches' mode of action in democratic societies is, therefore, what I would call an "inclusive prophetism" based on Biblical truths and supported by good arguments in the public discourse. 
NGTT: Oopbron - http://ngtt.journals.ac.za

In terms of theological paradigms we may say: Where dictatorships have allowed room for the development of civil societies, liberation theology has to be developed further into public theology. The latter provides the grounding for church based inputs in public discussions in pluralistic democratic societies. In such societies, voters decide deeplyethically relevant political questions by way of democratic elections. Therefore, the churches, in order to reach the public, have to be "bilingual". That is to say they must have a clear theological profile and speak a biblical theological language while speaking the language of public discourse and showing why their contributions to the debate in civil society make sense, not only to Christians, but to all people of good will.

Prophetic speech, therefore, must be related to discourse as well as dialogue. This leads me to a brief discussion of a third and final false alternative to be overcome.

\section{Moral rigour vs. discursive openness}

Church statements have often been accused of moral rigour. Those who make the accusations usually say that moral rigour does not replace expertise in the field. However, there is also a frequent attack from the opposite side. The word "experts"sometimes becomes pejorative. Experts are people who believe in and work with numbers and often ignore the stories of suffering of the victims of grave injustices. The statistics given by experts that, for example, show certain successes in fighting poverty are countered by the moral scandal of undoubtedly still existing poverty. Weneed to move beyond the false alternative of numbers versus stories, of moral outrage versus sober statistical analysis.

If economists can convincingly show that certain mechanisms have increased participation of the poor, we need to leave all political prejudices behind and learn from it. There must be completely open discourse regarding the best ways to overcome poverty and ecological destruction. We need as much data as possible to judge what works and what does not.

At the same time, the moral rigour in pursuing these goals cannot be strict enough. Deep solidarity with the victims of human made suffering is exactly the reason why the best ways to overcome their suffering should be searched for as thoroughly as possible. Only complete discursive openness can ensure that effective ways to a better future are not overlooked only because they do not fit our political worldview or our common intellectual designs. Moral rigour also needs radical curiosity. Sometimes it will be a desperate curiosity; at other times it will be a hopeful curiosity. But it will live from the eschatological vision of God's kingdom and it will breathe the air of shalom which is promised to us on earth.

\section{Conclusion}

I conclude with an example of new efforts to move beyond the false alternatives which I have described. From 11 to 13 October 2010 leading representatives of German and South African churches met during a consultation in Stellenbosch, South Africa, joining global church bodies such as the World Council of Churches, the World Communion of Reformed Churches and the Lutheran World Federation or bilateral church projects such as the German and South African Joint Globalisation project (Boesak, Weusmann and AmjadAli 2010 and Lombard 2010) in trying to reach a new consensus between North and South on the ethical foundations of globalisation and its consequences. The meeting included church leaders, theologians and economists ranging from the president of the World Communion 
NGTT Deel 54, Nommers $3 \& 4$, September en Desember 2013

of Reformed Churches and a representative of the World Council of Churches' process on Wealth Poverty and Ecology to the chairperson of the Social Chamber of the EKD, which had published several public memorandums with a quite different tone not long ago. Atthe final meeting participants discussed twenty theses that had met with wide ranging consensus. In light of the different approaches that the churches of the South and those of the North have taken, this "Stellenbosch consensus" is remarkable and can possibly strengthenalready existing efforts of ecumenical bodies to move beyond unfruitful polarisations.

This is only one initiative among many that are necessary to unify the voices of the churches worldwide in order to be at the forefront of a new global movement to open the door to a world for us all where we can live with dignity and where nature is seen as a precious gift from a Creator who, in the end, has "got the whole world in his hands".

\section{BIBLIOGRAPHY}

BedfordStrohm, H. 2008. Poverty and Public Theology. Advocacy of the Church in Pluralistic Society. International Journal for Public Theology 2(2), 144-162.

Boesak, A., Weusmann, J. and AmjadAli, C. 2010. Dreaming a Different World. Globalisation and Justice for Humanity and the Earth. The Challenge of the Accra Confession for the Churches. Uniting Reformed Church of South Africa/EvangelischReformierte Kirche, Germany.

Bonhoeffer, D. 1972. Letters and Papers from Prison. New York, NY: Macmillan. Bonhoeffer, D. 2005. Ethics. Minneapolis, MN: Augsburg Fortress.

Brubaker, P. and Mshana R. (eds.). 2010. Justice not Greed. Geneva:WCC.

Diefenbacher, H. 2011. Climate Change and the (Economic) Value of Nature - The Role of Economic Thinking in the Public Sphere. In Deane Drummond, C. and BedfordStrohm, H. (eds.), Religion and Ecology in the Public Sphere. London: Continuum, 77-88.

Duchrow, U. 1987. Global Capitalism: A Confessional Issue for the Churches? Geneva:WCC. Freudenberg, M. 2009. Economic and Social Ethics in the Work of John Calvin. In Boesak A. and Hansen, L. (eds.), Globalisation. The Politics of Empire, Justice and the Life of Faith. Stellenbosch: Sun Press, 153-172. United Nations Human Development Report (UNHDR) 2010. Summary online at: http://hdr.undp. org/en/mediacentre/summary/. [2011, March 20].

Körtner, U. 2008. Calvinismus und Kapitalismus. In Hirzel, M. E. and Sallmann, M. (eds.). 1509 Johannes Calvin - 2009. Sein Wirken in Kirche und Gesellschaft. Essays zum 500. Geburtstag. Zürich: Theologischer Verlag, 201-217.

Koopman, N. N. 2010. Human Dignity in the Context of Globalisation. In Boesak, A. and Hansen, L. (eds.). Globalisation II: Global Crisis, Global Challenge, Global Faith. An Ongoing Response to the Accra Confession. Stellenbosch: Sun Press, 231-242.

Lombard, C. 2010. "Globalisation as a Challenge to the Churches": Theological Foundations for a Reformed Contribution to the Debate. In Boesak, A. and Hansen, L. (eds.). Globalisation II, 243-263.

Naudé, P. 2010. Neither Calendar Nor Clock. Perspectives on the Belhar Confession. Grand Rapids, Ml: Eerdmans.

Nürnberger, K. 2005. Martin Luther's Message for Us Today. A Perspective from the South. Pietermaritzburg: Cluster.

Panti Filibus, M. 2010. Justice not Greed: Biblical Perspectives on Ethical Deficits of the Present Global Financial System. In Brubaker, P. and Mshana R. (eds.). Justice not Greed. Geneva:WCC, 45-59.

Papaderos, A. 2005. Aspekte orthodoxer Sozialethik. In Gabriel, I., Körtner, U. and Papaderos, A. Perspektiven ökumenischer Sozialethik. DerAuftrag der Kirchen im größeren Europa. Mainz: Mathias Grünewald, 23-126.

Raiser, K. 2009. Globalisierung in der ökumenischethischen Diskussion. Verkündigung und Forschung 54

6. The Stellenbosch consensus can be downloaded from: http:/www.unibamberg.de/fileadmin/uni/ fakultaeten/ppp_lehrstuhle/ evangelische_theologie_1/pdf_Dateien/Globalization_Stellenbosch_ consensus_final.pdf. 
NGTT: Oopbron - http://ngtt.journals.ac.za

(1) Jan., 633.

Smit, D. J. 2007. Essays in Public Theology. Collected Essays 1. Conradie, E. M. (Ed.) Stellenbosch: Sun Press.

Smit, D. J. 2009. Schreie nach Leben, Ethische Reaktionen auf Globalisierung mit (süd) afrikanischer Stimme. Verkündigung und Forschung 54 (1), Jan., 59-69.

Swiss Church Federation. 2005. Globalance. Christian Perspectives on Globalisation with a Human Face. Bern: Schweizerischer Kirchenbund.

\section{KEY WORDS}

Public Theology

Poverty and Ecology

Globalisation

Church Response

Sources of Christian involvement

\section{TREFWOORDE}

Publieke Teologie

Armoede en ekologie

Globalisasie

Kerklike reaksie

Bronne van christelike betrokkenheid

Contact Details/Kontakbesonderhede

Prof Heinrich Bedford-Strohm

Universität Bamberg

Markusplatz 3

D-96045 Bamberg

Germany

E-mail: heinrich.bedford-strohm@uni-bamberg.de 